\title{
Alanya Rüşdiye Mektebi (1861-1913)
}

\section{ALi RIZA GÖNÜLLÜ*}

\begin{abstract}
ÖZ
Osmanlı Devleti'nin yenileşme döneminde kurulan eğitim kurumlarından birisi rüşdiyelerdir. Bu mekteplere sıbyân mekteplerinden mezun olan talebeler kabul edilmektedir. Rüşdiye mekteplerinin erkek, kız ve askeri rüşdiyeler gibi çeşitleri bulunmaktadır. Alanya'da da medrese ve sıbyân mektebi gibi geleneksel eğitim kurumlarının yanında, Tanzimat Döneminden itibaren modern eğitim kurumları da açılmaya başlamıştır. Bunların başında da 1861'de Alanya'da hayırsever insanlar tarafından inşa edilen ve hizmete giren rüşdiye mektebi gelmektedir. Rüşdiye Mektebi açıldıktan sonra, devlet tarafından buraya muallim ataması yapılmıştır. Bu mektepte eğitim gören talebelerin ders kitapları, Maarif Nezareti tarafından gönderilmiş ve bedeli karşıl1ğında talebelere verilmiştir. Alanya Rüşdiye Mektebi'nde görev yapan muallimler maaş ve harcırah almışlar, yeterli hizmet süresini tamamlayan muallimler de emekliye ayrılmışlardır. Alanya maarif teşkilatı, idari ve mali yönden teftiş edilmiştir. Ayrıca Alanya Rüşdiye Mektebi'nde görev yapan muallimler, haklarında bir şikâyet meydana geldiği zaman soruşturma geçirmişlerdir. 6 Ekim 1913 tarihli Tedrisat-1 İbtidaiye Kanun-u Muvakkati'nin yürürlüğe girmesi neticesinde, ülkede bulunan diğer rüşdiye mektepleri gibi, Alanya Rüşdiye Mektebi de kapanmıştır.
\end{abstract}

Anahtar sözcükler: Eğitim, medrese, Rüşdiye mektebi, muallim, maaş, emekli.

Dr., Milli Eğitim Bakanlığı, Alanya Mesleki ve Teknik Anadolu Lisesi/ANTALYA E-posta: argonullu@hotmail.com 


\section{Giriş}

Bütün İslam dünyasında olduğu gibi, Osmanlı Devleti’nde de örgün ve B yaygın eğitim kurumlarının varlığı bilinmektedir. Bu devlet zamanında eğitim ve öğretim, genel ölçüde örgün eğitim kurumlarının başında gelen medreselere dayanıyordu. Bunun yanında sarayda enderûn-i hümâyûn, acemi oğlanlar ve yeniçeri ocakları, saray dı̧̧ında medreselere mahreç olan sıbyân mektepleri mevcuttu. Ayrıca yaygın eğitim kurumlarından kabul edilen ve her sinıftan halkı tarikat disiplini altında yetiştirmeyi hedef alan tekkeler de diğer eğitim kurumları arasında bulunuyordu (Uzunçarşılı 1984: 2, Baltacı 1976: 16).

Alanya'da da tarih içinde geleneksel örgün ve yaygın eğitim kurumlarının varlığını görmekteyiz (166 Numaralı Muhâsebe-i Vilâyet-i Anadolu Defteri (937/1530) Hudâvendigâr, Biga, Karesi, Saruhân, Aydın, Menteşe, Teke ve Alâiye Livaları 1995: 156). XVI. yüzyılın ilk yarısına ait bilgilere göre, Alanya'da mevcut olan örgün eğitim kurumlarından birisi Alanya'nın Taş $\mathrm{Pa}$ zarı Mahallesi'nde bulunan Kemal Kadı Medresesi, diğeri de Alanya'nın Oba Köyü'nde bulunan Oba Köyü Medresesi'dir ${ }^{1}$. Alanya’da bu dönemde örgün eğitim kurumlarının yanında, dini hizmetlerle birlikte yaygın eğitim kurumu görevini de yerine getiren birçok cami, mescit ve zâviye de bulunmaktadır (1995: 156).

XVII. yüzyılda Alanya'yı ziyaret eden Evliya Çelebi de (1611-1682) Alanya Kalesi'nin aşağı mahallesinde 2 medrese ile 6 sıbyân mektebinin varlığından, Alanya'nın Şıhlar Köyü'nde de 1 medresenin bulunduğundan bahsetmektedir (Evliya Çelebi Seyahatnamesi 1996: 9/28-29).

Osmanlı Devleti'nde eğitimde modernleşme çalışmalarının başladığı XIX. yüzyılda Alanya Kazası'nda da; medreselerle birlikte, sıbyân mektepleri ile rüşdiye mektebinin varlı̆̆ görülmektedir. Mesela; 1874 yılında Alanya Kazası'nda 9 sıbyân mektebi, 1 rüşdiye mektebi ve 5 medrese ${ }^{2}$, Alanya'nın Manavgat Nahiyesi'nde de 5 sıbyân mektebi mevcuttu. Aynı yıl Alanya

1 Oba Medresenin XIV. Yüzyılın ikinci yarısında yapıldığı bilinmektedir. Abdullah Kuran, "Karamanlı Medreseleri”, Vakifar Dergisi, Sayı:8, Ankara 1969, s.214.

2 Osmanlı Devleti'nin son döneminde Alanya halkı, , gençlerin Alanya dışında bulunan medreselerde eğitim görmesi konusunda hassas davranmış; bunlardan bir kısmı Osmanlı Devleti'nde mahkemelere kadı yetiştirmek için 1854 yılında Muallimhane-i Nüvvâb isimi ile İstanbul'da kurulan, daha sonra Mekteb-i Nüvvâb, Mekteb-i Kudât, Medresetü'l Kudât ismini alana medresede okumuşlardır. Bu medreseden 14 Mart 1858 ile 22 Ekim 1902 tarihleri arasında on yedi Alanyalı genç mezun olmuştur. Bu konuda bakınız; Mehmet İpşirli, "Medresetü'l Kudât Maddesi”, Türkiye Diyanet Vakfi İslam Ansiklopedisi, İstanbul 2003, 28/343; İlmiye Salnamesi, Dârü'l Hilafeti'l Âliye Matbaa-i Amire 1334, s.690-720. 
Kazası'nda bulunan sıbyân mekteplerinde 300 kız ve 800 erkek, Manavgat Nahiyesi'nde bulunan sıbyân mekteplerinde de 100 kız ve 250 erkek öğrenci öğrenim görüyordu. Yine Alanya Rüşdiye Mektebi’nde 40 ve medreselerde de 62 öğrenci bulunuyordu (Gönüllü 2008: 24).

Alanyadda Müslüman halkın çocuklarının devam ettiği sıbyân okullarının yanında, burada yaşayan gayrimüslim halkın çocuklarının eğitim gördüğü sıbyân okulu da mevcut olmuştur. Mesela; 1903 yılında Alanya Kazası'nda Rum cemaatine ait 1 adet ruhsatı olmayan erkek ve kız sıbyân okulu bulunuyordu. Aynı yıl bu okulda 85 erkek ve 65 kı öğrenci öğrenim görüyordu (Salname-i Nezareti Maarif-i Umumiye 1321: 596).

Alanya Kazası'nda, ihtiyaç meydana geldiği zaman yeni mektepler de açılmıştır. Mesela; XIX. yüzyılın son yıllarında Alanya'da yeni ibtidai mektepler için, bir bina inşa edilerek, bu binanın alt katında 7 dükkân, üst katında da 20,5 metre boyunda 10,5 eninde 2 adet ibtidai mektep yapılmıştır. İnşası tamamlanan bu mektepler kurbanlar kesilerek ve padişaha dualar edilerek resmi olarak açılmıştır. Alanya'da hizmete giren ibtidai mektepler ve bu mekteplerin resmi açılış töreni hakkında Alanya Kaymakamlığı tarafından Konya Vilayeti haberdar edilmiştir. Konya Vilayeti de 23 Nisan 1896'da Maarif Nezareti'ne konu hakkında bilgi vermiştir (BOA. MF. MKT. 315: 31. L.1). Maarif Nezareti tarafindan 12 Mayıs 1896'da Matbuat Dâhiliye Dairesi'ne de, Alanya'da iki ibtidai mektebin resmi açılış töreninin yapilarak, hizmete girdiği bildirilmiştir (BOA. MF. MKT. 315: 31. L.2).

1917 yılında da Antalya Mutasarrıflı̆̆ tarafindan Alanya Kazası'nda bir ana mektebi açılarak, bu okula muallim görevlendirilmesi için bir karara alınmıştır( BOA. DH. UMVM. 151: 59, Gönüllü 2010: 69).

Bunun yanında mahalli eşraf ve hayırsever insanlar tarafindan Alanya'da bir idadi mektebinin açılması için teşebbüse geçilmiştir. Bu konu hakkında Alanya Belediye Reisi Talat Bey, Eşraftan Hacıkadirzade Hüseyin Şükrü Bey, Eşraftan Azakzade İzzet Bey ve Eşraftan Halim Ağazade Mehmet Bey tarafindan 27 Şubat 1918 tarihinde Dâhiliye Nezareti’ne bilgi verilmiştir (BOA. DH. UMVM. 32: 74). Fakat halkın Alanya'da bir idadi mektebi açma teşebbüsü Osmanlı döneminde netice vermemiştir ${ }^{3}$.

3 Cumhuriyet döneminin ilk yıllarında Alanya'da orta dereceli bir okulun açılması için bir çalışma yap1lıp yapılmadığı bilinmemektedir. Ancak 1958 yılında Alanya'da Özel Lise Açma ve İşletme Derneği kurulmuştur. Derneğin kurucuları Fuat Salur, Halim Tokuş, Mithat Tokuş, İzzet Azakoğlu, Şevket Tokuş, Şevki Gücüoğlu, Muhittin Sadullahoğlu, Mevlüt Arıkan ve Ahmet Bekrioğlu idi. Bu dernek tarafından Alanya Özel Lisesi 28 Eylül 1959 tarihinde hizmete açılmış ve 1959-1960 ders yılı çalışmalarına başlamıştır. Alanya Özel Lisesi'nin açılış törenine Antalya Valisi Niyazi Akı da katılmış ve bir konuşma yapmıştır. Bu konuda bakınız; Ali Rıza Gönüllü, Cumburiyet Döneminde Antalya (19231960), İstanbul 2010, s.348. 
Burada Osmanlı Devleti’nin modernleşme döneminde eğitim hayatına giren rüşdiye mekteplerinin genel işleyişi üzerinde durularak, şimdiye kadar üzerinde çalışma yapılmamış olan Alanya Rüşdiye Mektebi hakkında bilgi verilecektir.

Bu çalışmada, arşiv vesikaları ile birinci ve ikinci el kaynakları tarama yöntemi kullanılmıştır. Veriler toplanarak analiz ve değerlendirme sürecinden sonra sonuca ulaşılmıştır.

Faydalanılan kaynaklar arasında Başbakanlık Osmanlı Arşivi'ndeki Bab-1 Ali Belgeleri içinde yer alan Sadaret Mektûbi Kalemi Meclis-i Vâlâ Yazışmalarına Ait Belgeler ile Meclis-i Vâlâ Riyâseti Belgeleri, Dâhiliye Nezareti kısmında bulunan Umûr-1 Mahalliye-i Vilâyât Müdüriyeti Belgeleri ile Maarif Nezareti kısmında bulunan Mektûbi Kalemi Belgeleri bulunmaktadır.

Bununla birlikte, İlmiye Salnamesi, Salname-i Nezareti Maarif-i Umumiye ve Konya Vilayeti Salnameleri başvurduğumuz diğer kaynaklardandir. Konu ile ilgili kaynak eserler ile basılı belgelerden de faydalanılmıştır.

Ayrıca Osmanl eğitim sistemini ve rüşdiye mekteplerini konu alan eser ve makalelerden istifade edilmiştir ${ }^{4}$.

Alanya Rüşdiye Mektebi konusu; Rüşdiye Mekteplerine Dair Hukuki Çalışmalar, Alanya Rüşdiye Mektebi, Muallimler, Muallimlerin Maaşı, Muallimlerin Tayin ve Emeklilikleri, Ders Kitapları, Teftiş ve Soruşturmalar gibi başlıklar altında incelenecektir.

\subsection{Rüşdiye Mekteplerine Dair Hukuki Çalı̧̧malar}

Rüşdiye kelimesi, rüşde vasıl olan çocuklara mahsus demektir. Mekteb-i Rüşdi, Mekâtib-i Rüşdiyye gibi (Şemseddin Sami 1989: 664). Rüşdiye mektebi terimi ise, Osmanlı Türkçesi’nde ortaokul karşıllğı olarak kullanılmıştır (Devellioğlu 1998: 902).

II. Mahmud devrinde, sıbyân mekteplerinin yetersiz olduğu anlaşılınca, 1838 y1lında bunların ıslah edilmesi yoluna gidilmiş, sıbyân mekteplerinin üstünde sınıf-1 sani mekteplerinin açılmasına karar verilmiştir. Fakat daha sonra bu mekteplerin adı, padişah tarafindan rüşdiye olarak değiştirilmiştir (Koda-

4 Ülkemizde bu konuda yapılan çalışmalar arasında Mustafa Ergün (İkinci Meşrutiyet Döneminde Eğitim Hareketleri, Ankara 1996), Uğur Ünal (II. Meşrutiyet Öncesi Osmanlı Rüşdiyeleri (1897-1907), Ankara 2015) ve Ayssegül Altınova’nın (Osmanl Modernleşmesinde Rüsdiye Mektepleri, Ankara 2010, Gazi Üniversitesi Sosyal Bilimler Enstitüsü Tarih Ana Bilim Dalı Yakınçă̆ Bilim Dalı Basılmamış Doktora) eserleri başta gelmektedir. 
man 1980: 148). Rüşdiye mekteplerinin açılmasını hazırlayan süreç, Sultan Abdülmecid'in 1845 yılında, ülkede Avrupa standartlarında yeni bir eğitim sistemi kurulmasını öngören bir ferman yayınlaması ile başlamıştır. İlk rüşdiye mektebi de 1847 yılında İstanbul'da Davut Paşa Mektebi'nde açılmıştır. Daha sonraki yıllarda İstanbul'da ve ülkenin belli başlı şehirlerinde yeni rüşdiye mekteplerinin açılmasına devam edilmiştir (Ergün 1996: 295, Öztürk 2008: 35/301).

Rüşdiyelerin; Erkek Rüşdiyeleri (Altınova 2010: 119) , Kız Rüşdiyeleri (Altınova 2010: 152, Görür 2015: 312), Nısf-1 (Nîm) Rüşdiyeleri (Altınova 2010: 169) ve Askeri Rüşdiyeler (Altınova 2010: 173, Türkol 2007: 7) gibi çeşitleri bulunmaktadir.

1867 yılına kadar rüşdiye mekteplerine yalnız Müslüman talebe alınmaktayd. Bu tarihten itibaren Hıristiyan çocukların da bu mekteplere alınması prensip olarak kabul edilmiştir. Bundan dolayı rüşdiye mekteplerine girebilmek için, adayların Türkçeden imtihana girmeleri şartı getirilmiştir (Kodaman 1980: 150-151).

Osmanlı'nın modernleşme döneminde eğitim sahasında hazırlanan ilk kapsamlı hukuki düzenleme 1869 tarihli Maarif-i Umumiye Nizamnamesi'dir. 198 maddeden meydana gelen bu nizamnamede; Osmanlı Devleti'nde eğitim kurumları iki kısma ayrılmaktadır. Bunlardan birisi genel mektepler, diğeri özel mekteplerdir. Bu nizamnameye göre, tahsil aşamaları da üçe ayrılmıştır. Bunlardan birincisi sıbyân ve rüşdiye mektepleri, ikincisi idadiye ve sultaniye mektepleri ve üçüncüsü de yüksek mekteplerdir (Madde 1-2) (Maarif-i Umumiye Nizamnamesi 1286: 3-7).

1869 tarihli Maarif-i Umumiye Nizamnamesi'nde rüşdiye mekteplerini ilgilendiren maddelerden bazıları şunlardır;

"Beş yüz haneyi aşan yerlerde halkı sırf İslam olan yerlerde İslam, sırf Hıristiyan olan yerlerde Hıristiyan rüşdiye mektepleri olacaktır. Bununla birlikte halkı İslam ve Hıristiyan karışık olan yerlerde İslam ve Hıristiyanlar için ayrı rüşdiye mektepleri aç1labilecektir. Bunun için adı geçen cemaatlerin yüz haneyi geçmesi gerekmektedir. Rüşdiye mekteplerine talebe sayısına göre birer veya ikişer adet muallim-i evvel ve muallim-i sani verilecektir. Ayrıca her rüşdiye mektebinin bir mubassırı ve bir hademesinin bulunması gerekmektedir" (Maarif-i Umumiye Nizamnamesi 1286: 8-9).

Bu nizamnamede aynı kuralların kız rüşdiye mekteplerinin açılabilmesi için de geçerli olduğu ifade edilmiş (Maarif-i Umumiye Nizamnamesi 1286: 11); ancak kız rüşdiye mekteplerinde ikiden dörde kadar muallime ile Ameliyat-1 
Hayatiye ve Musikî dersleri için birer hoca görevlendirilmesi hüküm altına alınmıştır (1286: 11).

Erkek ve kız rüşdiye mekteplerinde tahsil müddetinin dört y1l olduğunu (Maarif-i Umumiye Nizamnamesi 1286: 9,12) ortaya koyan adı geçen nizamname, bu mekteplerde; "Mebâdî-i Ulûm-i Diniye, Lisân-i Osmanî Kavâidi, İmlâ ve İnşa, Tertib-i Cedid Üzere Kavâid-i Arabiye ve Farisiye, İlm-i Hesap, Defter Tutmak Usulü, Tersim-i Hudut, Mebâdî-i Hendese, Tarih-i Umumî, Tarih-i Osmanî, Coğrafya, Jimnastik ve istekli olan öğrenciler için dördüncü sınıfta Fransızca gibi derslerin okutulacağını" belirtmiştir (1286: 9). Bununla birlikte; "kız rüşdiye mekteplerinde bu derslerin yanında Tedbîr-i Menzil, nakışa medar olacak kadar Resim, Müntahabât-1 Edebiyye ve istekli talebeler için Musikî gibi dersler bulunduğunu" ifade etmiştir (1286: 12).

1869 tarihli Maarif-i Umumiye Nizamnamesi'nin yürürlüğe girmesinden sonra, rüşdiyelerin işleyişini konu alan iki adet iç talimat yayımlanmıştır. Bunlardan birisi, İstanbul'da bulunan rüşdiye mektepleri için hazırlanmı̧̧ olan Dersaadet Mekâtib-i Rüşdiyesinin İdare-i Dâhiliyesine Mahsus Talimat'tır (Salname-i Nezareti Maarif-i Umumiye 1316: 297-311). Diğeri de İstanbul haricinde hizmet veren rüşdiye mekteplerinin işleyişini anlatan, Taşra Mekâtib-i Rüşdiyesinin İdare-i Dâhiliyesine Mahsus Talimat'tır (1316: 311325).

Burada konu ile ilgili olmasından dolayı, Taşra Mekâtib-i Rüşdiyesinin İdare-i Dâhiliyesine Mahsus Talimat üzerinde bir nebze durmak gerekmektedir. 50 maddeden meydana gelen bu talimatta; rüşdiye mekteplerinin Maarif Nezareti'nin idaresi altında olduğu, taşra rüşdiyelerinde görev yapan muallim, mubassır ve hademelerin vilayet maarif müdürlüklerine bağlı oldukları, rüşdiye mekteplerinin muallim-i evveller tarafindan talimata uygun olarak idare edileceği beyan edilmiştir. Ayrıca bu talimatta; muallimlerin, talebelerin ve hademelerin yapacakları görevler izah edilmiş, bunun yanında talebelere verilecek ödüller ile talebe ve muallimlere verilecek cezalar ortaya konulmuştur. Talebeye dayak atılmayacağı ve hapis edilmeyeceği de bu talimatta hüküm altına alınmıştır. Yine bu talimata göre, rüşdiye mekteplerinde demirbaş defterleri, isim defterleri, devam defterleri ve muhtelif masraflar defterlerinin kullanılması gerekmektedir (Salname-i Nezareti Maarif-i Umumiye 1316: 311).

Osmanlı Devleti'nin son yıllarında rüşdiye mekteplerinin işleyişini belirleyen iç talimatların yanında, bu mekteplerin haftalık ders programları ile derslerin içerikleri üzerinde de durularak, bu konular hakkında muhtelif çalışmalar yapılmıştır. 1869 tarihli Maarif-i Umumiye Nizamnamesi'nde rüşdiye 
mekteplerinde okunacak dersler toplu olarak verilmiş, ancak sınıflarda hangi derslerin haftada kaç saat okutulacağ gösterilmemişti. Daha sonra yürürlüğe giren haftalık ders programlarında ise, sınıflara göre hangi derslerin kaç saat okutulacağ 1 ve bu derslerde hangi konulara yer verileceği tespit edilmiştir. Rüşdiye mekteplerinde uygulamaya konulan ders programları arasında: Umûm Mekâtib-i Rüşdiye ve İdadiyede Okunan Ulûm ve Fünûnun Haftalık Aded-i Dürûsunı Mübeyyin Cetvel (Salname-i Nezareti Maarif-i Umumiye 1316: 191), Umûm Mekâtib-i Rüşdiyede Okunan Ulûm ve Fünûnun Haftalık Aded-i Dürûsunı Mübeyyin Cetvel (1316: 358), İnas Rüşdiyelerine Mahsus Ders Programı (1316: 393), Umûm Mekâtib-i Rüşdiyeye Mahsus Olarak Bu Kere Tadilen Tertib Edilen Ders Programı gibi metinler bulunmaktadır (Umûm Mekâtib-i Rüşdiyeye Mahsûs Olarak Bu Kere Tâdilen Tertip Edilen Ders Programıdır 1315: 3, Ünal 2015: 17 vd.).

1897 y1lında neşredilen Umûm Mekâtib-i Rüşdiyeye Mahsus Olarak Bu Kere Tadilen Tertib Edilen Ders Programı'nda, rüşdiye mekteplerinin üç yıl olduğu ifade edilmiş ve bu üç yıl içinde haftalık okunacak dersler ile ders saatleri aşağıdaki tabloda gösterildiği gibi tespit edilmiştir. Bu ders programına göre XIX. yüzyılın son yıllarında rüşdiye mekteplerinin 1 .sınıfinda 18 saat, $2 . s ı n ı f i n d a ~ 20$ saat ve 3 . sınıfında 23 saat ders yer almıştır. Ayrıca bu haftalık ders programımda en fazla ders saatine, Türkçe dersinin sahip olduğu görülmektedir ( Umûm Mekâtib-i Rüşdiyeye Mahsûs Olarak Bu Kere Tâdilen Tertip Edilen Ders Programidir 1315: 3).

Bununla birlikte, 1869 tarihli Maarif-i Umumiye Nizamnamesi’nde olduğu gibi ${ }^{5}$, bu ders programında da, yabancı dil olarak Arapça ve Farsça Dersleri'nin yanında, devletin modernleşme politikası ile yakından ilgili olarak Fransızca Dersi de zorunlu ders olarak yer almıştır ( Umûm Mekâtib-i Rüşdiyeye Mahsûs Olarak Bu Kere Tâdilen Tertip Edilen Ders Programıdır 1315: 3).

\begin{tabular}{|l|l|l|l|}
\hline Derslerin İsmi & $\begin{array}{l}\text { Birinci Sene } \\
\text { Haftada(saat) }\end{array}$ & $\begin{array}{l}\text { İkinci Sene } \\
\text { Haftada(saat) }\end{array}$ & $\begin{array}{l}\text { Üçüncü Sene } \\
\text { Haftada(saat) }\end{array}$ \\
\hline $\begin{array}{l}\text { Maa Tecvîd Kurân-1 Kerim } \\
\text { ve Ulûm-u Diniye }\end{array}$ & 3 & 2 & 2 \\
\hline Türkçe & 7 & 6 & 4 \\
\hline Arabî & 1 & 2 & 2 \\
\hline Farisî & & 1 & 2 \\
\hline
\end{tabular}

5 Ancak bu nizamnamede Fransızca Dersi seçmeli ders olarak yer almıştır. Maarif-i Umumiye Nizamnamesi, İstanbul Matbaa-i Amire 1286, s.9. 


\begin{tabular}{|l|l|l|l|}
\hline Fransizca & & & 3 \\
\hline Hesap & 2 & 2 & 2 \\
\hline Hendese & & & 1 \\
\hline Coğrafya & 2 & 2 & 2 \\
\hline Tarih & & 2 & 2 \\
\hline Malûmât-1 Nâfia & 1 & 1 & 1 \\
\hline Hüsn-i Hatt & 1 & 1 & 1 \\
\hline Resim & 1 & 1 & 1 \\
\hline Toplam & 18 & 20 & 23 \\
\hline
\end{tabular}

Tablo 1: 1897 Yılında Rüşdiye Mekteplerinde Sınıflara Göre Haftada Okutulan Dersler ve Süreleri.

(Umûm Mekâtib-i Rüşdiyeye Mahsûs Olarak Bu Kere Tâdilen Tertip Edilen Ders Programıdır 1315: 3)

Böylece Osmanlı ülkesinde 1869 tarihli Maarif-i Umumiye Nizamnamesi ile rüşdiyelerin işleyişini konu alan iç talimatların ve haftalık ders programlarının uygulanmaya başlaması, eğitim sisteminin merkezileşmesi yolunda atılmış önemli adımlardan birisidir. Ayrıca adı geçen nizamname ile Maarif Nezareti'nin taşra teşkilatı da kurulmaya başlanmıştır. Yine yapilan bu mevzuat çalışmaları ile eğitime bir standart getirilmek istendiği görülmektedir. Bununla birlikte Osmanlı döneminde yapılan bu uygulamaların izlerinin, Cumhuriyet dönemi eğitiminde de yer aldığı bilinmektedir (Resmi Gazete 24 Haziran1973: 1).

Bütün bu mevzuat ve program çalışmalarına rağmen, 6 Ekim 1913 tarihli Tedrisat-1 İbtidaiye Kanun-u Muvakkati'nin yürürlüğe girmesi neticesinde rüşdiye mektepleri, öğretim süresi altı yıla çıkarılan ibtidai mekteplerin çatısı altına alınarak bağımsız mektep olarak faaliyet göstermesi uygulamasına son verilmiştir (Tedrisat-1 İbtidaiye Kanun-u Muvakkati 1329: 3-16, Öztürk 2008: 35/ 302).

Böylece Osmanlı Devleti’nde yaygın olarak 1847 yılından itibaren açılmaya başlayan rüşdiye mektepleri 66 yıl gibi bir süre bağımsız mektep olarak Türk eğitim sistemi içinde varlığını sürdürmüş, 1913 yılında da ortadan kalkmıştır. Görüldüğü gibi eğitimin modernleşmesi yolunda gerçekleştirilmiş olan önemli bir çalışma, fazla uzun ömürlü olamamıştır. 


\section{ALANYA RÜŞDIYYE MEKTEBİ}

XIX. yüzy1lın ortalarından itibaren, Osmanlı Devleti'nin merkezi olan İstanbul'da ve taşra şehirlerinde rüşdiye mekteplerinin açılmaya başlaması, Alanya'da da akis bulmuştur. Şöyle ki; Zağra-i Atik şehrinin hayırsever insanlarından Emin Bey tarafından Zağra'da eğitime katkı sağlamak üzere bir arsa bağ̣şlanmıştı. Bu arsa üzerine mahalli servet sahipleri tarafindan bir rüştiye mektebi inşa edilmişti (BOA. A. MKT. MVL. 124:152).

Emin Bey'in eğitime yaptığı hayır işleri Alanya'da da devam etmiştir; Adı geçen zat tarafından Alanya'da da hayır işlerinde kullanılmak üzere bir arsa bağışlanarak, bu arsa üzerine masrafları mahalli hayırsever insanlar tarafindan karşılanan, bir rüşdiye mektebi ile bunun bitişiğine bir cami inşa edilmişti. Bunun üzerine Maarif Nezareti tarafından Zağra ve Alanya'da yapılan mektepler için icap eden muallimlerin ve gerekli olan kitapların temini, ayrıca Emin Bey'in Terfi Rütbesi ile taltif edilmesi Sadaret'ten talep edilmişti. Sadaret de bu konu hakkında Maliye Nezareti'ne bilgi vermiş ve gereğinin yapılmasını istemiştir. Maliye Nezareti'nden Sadaret'e verilen cevabi yazıdan; taşrada rüştiye mektebi muallim-i evvellerine aylık 600'ar kuruş, muallim-i sanilerine aylık 300'er kuruş, bevvaplarına aylık 100'er kuruş maaş ve yıllık 2.000'er kuruş masarif-i müteferrika ödenmekte olduğu anlaşılmaktadır. Maliye Nezareti'nin verdiği bu bilgi, Sadaret tarafından Meclis-i Vâlâya havale edilmiştir. Maarif Nezareti'nin talebi, Meclis-i Vâlâda görüşülmüştür. Yapılan görüşme sonunda Emin Bey'e Terfi Rütbesi verilmesi teklifi kabul edilmemiştir. Ancak Zağra ve Alanya'da inşa edilen rüşdiye mektepleri için gerekli olan kitap bedelleri ile muallim ve bevvaplara yukarıda belirtilen miktarlarda maaşın tahsis ve tayin olunması talebi kabul edilmiştir. Daha sonra konu hakkında padişah iradesi yayınlanmıştır. Sadaret tarafından 28 Ocak 1861 tarihinde Maarif Nezareti’ne gönderilen yazıda, padişah iradesi hakkında bilgi verilmiş ve bu irade doğrultusunda gerekli işlemin yapılması, ayrıca ilgili kaymakamlıkların bilgilendirilmesi istenmiştir (BOA. A.MKT. MVL. 124:152).

Merkezi yönetim ile taşra yönetimi arasında gerçekleşen bu bilgi akışından bir müddet sonra, Alanya Rüşdiye Mektebi'ne muallim tayin edildiği görülmektedir (BOA. MVL. 715: 72). Ancak rüşdiye mektebinin Alanya’nın hangi mahallinde bulunduğu ve mektebin fiziki yapısı hakkında şimdilik fazla bir bilgiye ve adı geçen mektep ile ilgili görsel malzemeye rastlanamamıştır ${ }^{6}$.

6 Alanya Rüşdiye Mektebi binasının, bugünkü Hayate Hanım İlkokulu'nun kuzey kesiminde olabileceği söylenmektedir. Ancak Alanya Rüşdiye Mektebi ile ilgili elimizde resim vb. bir belge bulunmamaktadır. Kaynak kişi; Haşim Yetkin, Alanya 1939 doğumlu. Emekli öğretmen. 


\subsection{Muallimler}

1861 yılından itibaren kapandığı tarihe kadar Alanya Rüşdiye Mektebi’nde, birçok muallim çalışıştır. Bunlar arasında muallim-i evvel olarak Yahya Efendi (Konya Vilayeti Salnamesi 1285: 87), Abdülgafur Rüşdi Efendi (BOA. MF. MKT. 473: 35) 7 , Mehmet Rahmi Efendi (Salname-i Nezareti Maarif-i Umumiye 1321: 579), Halil Efendi (Konya Vilayeti Salnamesi 1322: 166), muallim-i sani olarak Sadullah Efendi (Konya Vilayeti Salnamesi 1285: 87), Mehmet Efendi (Konya Vilayeti Salnamesi 1303: 316), muallim-i salis olarak Ahmet Efendi (Salname-i Nezareti Maarif-i Umumiye 1316: 1157), Abdurrahman Efendi (Salname-i Nezareti Maarif-i Umumiye 1319: 1901), rika (hüsn-i hatt) hocası olarak Ali Efendi (BOA. MVL. 715: 72), Arif Efendi (Konya Vilayeti Salnamesi 1303: 316) ve Fehmi Efendi (Konya Vilayeti Salnamesi 1309: 218) gibi muallimler bulunmaktadır. Yine bu mektepte Süleyman Ağa (Konya Vilayeti Salnamesi 1291: 79), Hasan Ağa (Konya Vilayeti Salnamesi 1306: 245) ve Mustafa Ağa (BOA. MF. MKT. 435:6, Konya Vilayeti Salnamesi 1317: 207) gibi şahıslar bevvâb olarak çalışmışlardır.

Bunun yanında Alanya Rüşdiye Mektebi'nde 1868 tarihinden itibaren 1898 tarihine kadar 30 yıl görev yapan Muallim-i Evvel Yahya Efendi'nin, bu mektepte en uzun süreli çalışan muallim olduğu görülmektedir ( BOA. MF.MKT. 435:6, Salname-i Nezareti Maarif-i Umumiye 1316: 1157).

Alanya Rüşdiye Mektebi’nde öğrenin gören öğrencilerin sayısı hakkında da elde bazı yıllara ait veriler bulunmaktadır. Buna göre bu mektepte 1877'de 41 (Konya Vilayeti Salnamesi 1294: 96), 1879'da 60 (Konya Vilayeti Salnamesi 1296: 152), 1886'da 90 (Konya Vilayeti Salnamesi 1303: 316), 1898'de 94 (Konya Vilayeti Salnamesi 1316: 1157), 1899'da 52 (Konya Vilayeti Salnamesi 1317: 207), 1903'de 35 (Konya Vilayeti Salnamesi 1321: 579) ve 1906'da 45 (Konya Vilayeti Salnamesi 1322: 166) talebe öğrenim görmüştür. $\mathrm{Bu}$ verilere göre Alanya Rüşdiye Mektebi'nin ortalama yıllık talebe sayısı 59 'dur.

7 Bu muallimin ismi bazı yerlerde Abdülgaffar ve Abdülgafur olarak geçmektedir. Bu konuda bakınız; Konya Vilayeti Salnamesi, Konya 1317, s.207; BOA. MF. MKT. nr.435/6. 


\begin{tabular}{|c|c|c|c|c|c|c|}
\hline YILLAR & Muallim-i Evvel & Muallim-i Sani & Muallim-i Salis & $\begin{array}{l}\text { Rika (Hüsn-i } \\
\text { Hatt) Hocası }\end{array}$ & Bevvâb & $\begin{array}{l}\text { Talebe } \\
\text { sayıs1 }\end{array}$ \\
\hline 1864 & & & & Ali Efendi & & \\
\hline 1968 & Yahya Efendi & Sadullah Efendi & & Ali Efendi & & \\
\hline 1869 & Yahya Efendi & Sadullah Efendi & & Ali Efendi & & \\
\hline 1870 & Yahya Efendi & Sadullah Efendi & & Ali Efendi & & \\
\hline 1871 & Yahya Efendi & Sadullah Efendi & & Ali Efendi & & \\
\hline 1872 & Yahya Efendi & Sadullah Efendi & & Ali Efendi & & \\
\hline 1873 & Yahya Efendi & Sadullah Efendi & & Ali Efendi & & \\
\hline 1874 & Yahya Efendi & Sadullah Efendi & & Ali Efendi & Süleyman Ağa & \\
\hline 1875 & Yahya Efendi & Sadullah Efendi & & Ali Efendi & Süleyman Ağa & \\
\hline 1876 & Yahya Efendi & Sadullah Efendi & & Ali Efendi & Süleyman Ağa & \\
\hline 1877 & Yahya Efendi & Sadullah Efendi & & Ali Efendi & Süleyman Ăga & 41 \\
\hline 1878 & Yahya Efendi & Sadullah Efendi & & A.Riza Efendi & Süleyman Ağa & \\
\hline 1879 & Yahya Efendi & Sadullah Efendi & & Rıza Efendi & Süleyman Ağa & 60 \\
\hline 1881 & Yahya Efendi & & & Ali Efendi & Süleyman Ağa & \\
\hline 1882 & Yahya Efendi & & & Ali Efendi & & \\
\hline 1883 & Yahya Efendi & & & Ali Efendi & & \\
\hline 1884 & Yahya Efendi & & & Ali Efendi & & \\
\hline 1886 & Yahya Efendi & Mehmet Efendi & & Arif Efendi & & 90 \\
\hline 1888 & Yahya Efendi & Mehmet Efendi & & Arif Efendi & & \\
\hline 1889 & Yahya Efendi & Mehmet Efendi & & Arif Efendi & Hasan Ağa & \\
\hline 1890 & Yahya Efendi & Mehmet Efendi & & Arif Efendi & Hasan Ağa & \\
\hline 1892 & Yahya Efendi & Mehmet Efendi & & Fehmi Efendi & Hasan A ğa & \\
\hline 1894 & Yahya Efendi & Mehmet Efendi & & Fehmi Efendi & Hasan Ağa & \\
\hline 1896 & Yahya Efendi & Mehmet Efendi & & Fehmi Efendi & Hasan Ağa & \\
\hline 1898 & Yahya Efendi & Mehmet Efendi & Ahmet Efendi & Fehmi Efendi & & 94 \\
\hline 1899 & $\begin{array}{l}\text { Abdülgafur } \\
\text { Rüşdi Efendi }\end{array}$ & Mehmet Efendi & Ahmet Efendi & Fehmi Efendi & Mustafa Ağa & $52^{1}$ \\
\hline $1900^{2}$ & $\begin{array}{l}\text { Abdülgafur } \\
\text { Rüşdi Efendi }\end{array}$ & Mehmet Efendi & Ahmet Efendi & Fehmi Efendi & & 94 \\
\hline 1901 & $\begin{array}{l}\text { Abdülgafur } \\
\text { Rüşdi Efendi }\end{array}$ & Mehmet Efendi & $\begin{array}{l}\text { Abdurrahman } \\
\text { Efendi } \\
\end{array}$ & Fehmi Efendi & & 33 \\
\hline 1903 & $\begin{array}{l}\text { Mehmet Rahmi } \\
\text { Efendi }\end{array}$ & Sadullah Efendi & \begin{tabular}{|l|} 
Abdurrahman \\
Efendi \\
\end{tabular} & Fehmi Efendi & & 35 \\
\hline 1906 & Halil Efendi & Mehmet Efendi & & Fehmi Efendi & & 45 \\
\hline
\end{tabular}


(BOA. MVL. 715:72, Konya Vilayeti Salnamesi 1285: 87, Konya Vilayeti Salnamesi 1286: 78, Konya Vilayeti Salnamesi 1287: 90, Konya Vilayeti Salnamesi 1288: 80, Konya Vilayeti Salnamesi 1289: 73, Konya Vilayeti Salnamesi 1290: 74, Konya Vilayeti Salnamesi 1291: 79, Konya Vilayeti Salnamesi 1292: 79, Konya Vilayeti Salnamesi 1293: 80, Konya Vilayeti Salnamesi 1294: 96, Konya Vilayeti Salnamesi 1295: 99, Konya Vilayeti Salnamesi 1296: 152, Konya Vilayeti Salnamesi 1298: 148, Konya Vilayeti Salnamesi 1299: 157, Konya Vilayeti Salnamesi 1300: 60, Konya Vilayeti Salnamesi 1301: 56, Konya Vilayeti Salnamesi 1303: 316, Konya Vilayeti Salnamesi 1305: 242, Konya Vilayeti Salnamesi 1306: 245, Konya Vilayeti Salnamesi 1307: 219, Konya Vilayeti Salnamesi 1309: 218, Konya Vilayeti Salnamesi 1312: 183, Konya Vilayeti Salnamesi 1314: 183, Salname-i Nezareti Maarif-i Umumiye 1316: 1157, BOA. MF. MKT. 473: 35. L.1, Salname-i Nezareti Maarif-i Umumiye 1319: 1901, Salname-i Nezareti Maarif-i Umumiye 1321: 579, Konya Vilayeti Salnamesi 1322: 166).

Burada örnek olması bakımından, Osmanlı ülkesinde bulunan bazı rüşdiye mekteplerinde görevli olan muallimler ve muhtelif görevliler ile bu mekteplerin öğrenci sayıları hakkında da şunları ifade edebiliriz. Mesela; 1874 yılında Bolu Rüşdiye Mektebi'nde bir muallim-i evvel, bir muallim-i sani, bir hat muallimi, bir hizmetli ve 65 talebe vardı (Kılıç ve Tarhan 2014: 165). 1895 y1lında Biga Rüşdiye Mektebi’nde bir muallim-i evvel, bir muallim-i sani, bir hat muallimi, bir hademe ve 65 talebe bulunuyordu (Kaya 2007: 245). Yine Mersin Rüşdiye Mektebi'nin 1873-1903 yılları arasında ortalama talebe sayısı 44 olmuştur. Bununla birlikte 1903 yılında adı geçen mektepte, bir muallim-i evvel, bir muallim-i sani, bir muallim-i salis, bir hat muallimi, bir Fransizca muallimi, bir muayene memuru ve bir hademe bulunuyordu (Bozkurt 2008: 204).

Görüldüğg̈ gibi, bu mekteplerden Mersin Rüşdiye Mektebi’nde beş, diğgerlerinde üç muallim görev yapmaktadır. Alanya Rüşdiye Mektebi'nde de genellikle üç muallim görev yapmıştır. Ayrıca Alanya Rüşdiye Mektebi de dâhil olmak üzere, adı geçen mekteplerin talebe sayısı 100'den aşağıdadır.

$\mathrm{Bu}$ verilere göre bu mekteplerde, adı geçen mekteplerin hizmete girdiği dönem göz önüne alındığı zaman, muallim sayısının yeterli olduğu düşünülse bile, çağ nüfusunda okullaşma oranının fazla olmadığı görülmektedir.

\subsubsection{Muallimlerin Maaş 1}

Rüşdiye mektebinde görev yapan muallimlere ve diğer çalışanlara devlet tarafından aylık olarak belli miktarda maaş verilmiştir (Aydın 2011: 819). Bu mekteplerin muallimlerine ödenecek olan maaşlar ile ilgili olarak ilk düzen- 
leme 1869 tarihli Maarif-i Umumiye Nizamnamesi ile yapılmıştır. Bu nizamnamede rüşdiye mekteplerinde görevli olan muallim ve diğer çalı̧̧anların maaşının vilayet maarif idaresi sandığından karşılanacağı belirtilmiştir. Ayrıca rüşdiye mektebinde çalışan muallim-i evvelin aylık maaşının 800 kuruş, muallim-i saninin aylık maaşının 500 kuruş, mubassırın aylık maaşının 250 kuruş ve hademenin aylık maaşının 150 kuruş olacağ ifade edilmiştir. Yine bu görevlilere muhtelif masraflar için de yıllık 400'er kuruş tahsis edileceği ifade edilmiştir (Maarif-i Umumiye Nizamnamesi 1286: 8).

Ancak muallimlere verilen maaşta zaman içinde bazı değişiklikler meydana gelmişti. Bu nedenle aldıkları maaşın az olduğunu düşünen bazı rüşdiye mektebi muallimleri, maaşlarının arttırılması için Maarif Nezareti'ne başvurmuşlardı. Bunlar arasında Alanya Rüşdiye Mektebi'nde görev yapan muallimler de bulunuyordu. Mesela; Alanya Rüşdiye Mektebi Rıka (Hüsn-i Hatt) Muallimi Fehmi Efendi, aylık 33 kuruş maaş alıyordu. Fehmi Efendi, zaruri ihtiyaçlarının karşılanması için maaşının emsaline göre arttırılması konusunda Alanya Kaymakamlığı'na bir dilekçe vermiştir. Alanya Kaymakamlığı tarafından Fehmi Efendi'nin talebi Konya Vilayeti'ne bildirilmiştir. Konya Vilayeti Maarif Müdürlüğü de, Fehmi Efendi’nin emsaline göre az maaş aldığ 1 hususunda bir tespit yapmıştır. Daha sonra adı geçen müdürlük, 13 Haziran 1895 tarihinde Maarif Nezareti'ne gönderdiği yazıda, Fehmi Efendi’nin maaşının emsali seviyesine çıkarılmasını talep etmiştir (BOA. MF. MKT. 306: 4. L.1). Maarif Nezareti de bu talebi uygun görmüş ve Fehmi Efendi'nin maaşına aylık 47 kuruş zam yapılarak, maaşın 80 kuruşa çıkarılmasına karar vermiştir. Bu karar Maarif Nezareti tarafından Sadaret'e iletilmiştir. Sadaret de 25 Aralık 1895 tarihinde Fehmi Efendi'nin maaşına aylık 47 kuruş zam yapılarak, 80 kuruş olması hakkında bir padişah iradesinin çıkmasını sağlamıştır. Padişah iradesinin çıkmasından sonra Muhasebe tarafından da bu şekilde kaydı düzenlemiştir. Ayrıca Rüşdiye İdaresi tarafından padişah iradesine uygun olarak, Fehmi Efendi'ye yeni maaşın tebliğ tarihinden itibaren aylık 80 kuruş olarak ödenmesi istenmiştir (BOA. MF. MKT. 306: 4. L.2).

Maarif Nezareti24 Ocak 1896 tarihinde Konya Vilayeti Maarif Müdürlüğ̈’ne gönderdiği yazıda da, Alanya Rüşdiye Mektebi Rıka (Hüsn-i Hatt) Muallimi Fehmi Efendi'nin maaşının, padişah iradesine dayanarak aylık 47 kuruş zam yapılarak 80 kuruşa çıkarıldı̆̆ını ve kendisine tebliğ tarihinden itibaren maaşının aylık 80 kuruştan ita edilmesi gerektiğini bildirmiştir. Ayrıca bu konu ile ilgili olarak Fehmi Efendi'ye yapilan tebligat tarihinin bildirilmesi, ilk aylığından adı geçen zammın terk edilerek tevkif edilmesi ve makamı mahsusuna gönderilmesi talep edilmiştir (BOA. MF. MKT. 306: 4. L.3). 
Alanya Rüşdiye Mektebi Muallim-i Evvellerinden Abdülgafur Rüşti Efendi de, maaşına zam yapılması talebi ile Maarif Nezareti'ne başvuran muallimler arasında idi; Abdülgafur Rüşti Efendi, Dar-ül-Muallim-i Rüşdi'den mezun olmuş ve yirmi y1ldan fazla bir zamandan beri ülkenin muhtelif rüşdiye mekteplerinde muallim-i evvellik görevinde bulunmuştu. Bir yıldan beri de aylık 500 kuruş maaşla Alanya Rüşdiye Mektebi'nde muallim-i evvel olarak görev yapıyordu. Abdülgafur Rüşti Efendi 29 Ağustos 1899 tarihinde Maarif Nezareti'ne bir dilekçe göndermiştir. Adı geçen muallim, bu dilekçesinde almış olduğu 500 kuruş maaş ile 10 nüfus olan ailesini geçindiremediğini, ayrıca Alanya’nın iklimine bir türlü alışamadığını ifade etmiştir. Daha sonra da maaşına bir miktar zam yapılmasını veya maaşına zam yapılmazsa, aynı maaş ile İstanbul'a civar olan vilayet, liva veya kazalardan birisinin rüşdiye mektebine muallim-i evvel olarak tayin edilmesini talep etmiştir (BOA. MF. MKT. 473: 35. L.1).

Abdülgafur Rüşti Efendi'nin bu dilekçesi, Maarif Nezareti Rüşdiye Dairesi'nde görüşülmüştür. Ancak burada yapılan görüşme sonunda, İstanbul'un civarında bulunan mekteplerde görev yapan muallim-i evvellerin maaşlarının ekserisinin 400 kuruş olduğu, ayrıca Abdülgafur Rüşti Efendi’nin maaşına zam yapılması için bütçenin uygun olmadığı tespiti yapılmıştır (26 Eylül 1899) (BOA. MF. MKT. 473: 35. L.2).

$\mathrm{Bu}$ nedenlerden dolay1, Maarif Nezareti'nden 23 Ekim 1899 tarihinde Konya Vilayeti Maarif Müdürlüğüne gönderilen yazıda, Abdülgafur Rüşti Efendi'nin talebinin yerine getirilemeyeceği bildirilerek, bu durumun adi geçen muallime tebliğ edilmesi istenmiştir (BOA. MF. MKT. 473: 35. L.3).

$\mathrm{Bu}$ arada ülkenin değişik mekteplerinde görev yapan muallimlerin, muhtelif nedenlerden dolayı, maaş ve harcırahlarını alamadığı zamanlar da olmuştur. Bunlar arasında Alanya Rüşdiye Mektebi'nde görevli bir muallim de bulunmaktadır. Maaş ve harcırahını alamadı̆̆ı konusunda Maarif Nezareti'ne dilekçe ile başvuran ilgili muallim, bu dilekçesinde; 2 Eylül 1905 tarihinden itibaren Alanya Rüşdiye Mektebi’nde görev yaptığını, ancak maaş ve harcırahını alamadığını beyan etmiş ve konu ile ilgili yapmış olduğu müracaatların sonuçsuz kaldığını bildirerek, mağduriyetinin giderilmesini istemiştir. Bunun üzerine Maarif Nezareti'nden Konya Vilayeti'ne, konunun araştırılarak, gereğinin yerine getirilmesi konusunda talimat verilmiştir (5 Ekim 1905) (BOA. MF. MKT. 897: 66).

Yapılan araştırma sonunda, ilgili muallime maaş ve harcırahının, bunlara esas olacak belgelerin verilmemiş olmasından ödenmediği ortaya çıkmıştır. Bu konu hakkında 4 Mart 1906 tarihinde, Konya Vilayeti tarafından Maarif Nezareti'ne gerekli bilgi verilmiştir (BOA. MF. MKT. 897: 66). 
Görüldüğü gibi, devlet personeli tarafindan maaşların yetersiz olduğu ve geçim sıkıntısı çekildiği iddiası günümüzde olduğu gibi (Sönmez 1989: 81, Hürriyet Gazetesi 20 Kasım 2015: 1), Osmanlı Devleti'nin son dönemlerinde de gündemdeki yerini muhafaza etmiştir.

\subsubsection{Muallimlerin Tayinleri ve Emeklilikleri}

Alanya Rüşdiye Mektebi açıldıktan sonra, muallim-i evvel ve muallim-i saniler ile rıka hocaları bu mektebe tayin edilerek, görev yapmışlardır. Alanya Meclisi tarafından Maarif Nezareti'nden, Alanya Rüşdiye Mektebi rıka (hüsn-i hatt) hocalığına 1864 yılının Kasım ayının başlangıcından itibaren münasip miktar maaş tahsis edilerek, Ali Efendi'nin tayin edilmesi talep edilmiştir. Ayrıca Alanya Meclisi'nce, Ali Efendi'ye ait hatt numunesi, Maarif Nezareti'ne gönderilmiştir. Bu talep Maarif Nezareti'nce Meclis-i Maarif'e havale edilmiştir. Meclis-i Maarif de, Ali Efendi'nin talep edilen göreve atanmasını uygun görerek, adı geçen tarihten itibaren emsali gibi aylık $500 \mathrm{ku}-$ ruş maaş tahsis edilerek tayin edilmesini kabul etmiştir. Meclis-i Maarif'in Ali Efendi hakkındaki olumlu görüşü, Maarif Nezareti tarafından 13 Kasım 1865 tarihinde Sadaret'e bildirilerek, gerekli işlemin yapılması istenmiştir (BOA. MVL. 715: 72). Bir müddet sonra da Ali Efendi, Alanya Rüşdiye Mektebi'nde rıka (hüsn-i hatt) hocası olarak çalışmaya başlamıştır (Konya Vilayeti Salnamesi 1285: 87).

Ülkenin diğer rüşdiye mekteplerinde olduğu gibi,Alanya Rüşdiye Mektebi’nde görev yapan muallimler de, kanuni çalı̧̧ma süresini doldurduktan sonra emekliye ayrılmışlardır. Mesela; Alanya Rüşdiye Mektebi Muallim-i Evveli Yahya Efendi tarafından emekliye ayrılmak talebi ile verilen dilekçe, Konya Vilayeti tarafından Maarif Nezareti'ne gönderilmiştir. Daha sonra Yahya Efendi'nin dilekçesi, sandık müddetini gösteren cetvel ile muhasebe tarafindan tanzim edilmiş olan hesap pusulası Heyet-i Umumiye'de tetkik edilmiştir. Burada yapılan tetkik sonucunda Muallim-i Evvel Yahya Efendi'nin 37 y1l hizmeti bulunduğu ve Memurin-i Mülkiye Kararnamesinin 26. ve 42. maddeleri gereği 293 kuruş maaş ile emekliye ayrılabileceğine karar verilmiştir (29 Eylül 1898) (BOA. MF. MKT. 435: 6. L.1).

$\mathrm{Bu}$ arada Konya Vilayeti tarafindan 31 Ekim 1898 tarihinde Maarif Nezareti'ne gönderilen başka bir yazıda, Alanya Rüşdiye Mektebi Muallim-i Evveli Yahya Efendi'nin emekliye ayrıldığı bildirilmiş ve yerine yeterli mik- 
tarda maaşla muktedir bir muallimin tayin edilmesi talep edilmiştir (BOA. MF. MKT. 435:6. L.2) 8 .

Aynı tarihlerde Antalya Rüşdiye Mektebi, idadi mektebine dönüştürülmüştü. Bu nedenle Antalya Rüşdiye Mektebi Muallim-i Evveli Abdülgafur Rüşdi Efendi, başka bir okula tayin edilmesini talep etmişti. Bunun üzerine adı geçen muallim-i evvel, Konya Vilayeti tarafından emeklilik talebinde bulunan Alanya Rüşdiye Mektebi Muallim-i Evveli Yahya Efendi'nin yerine görevlendirilmiştir. Ayrıca 3 Kasım 1898 tarihinde de Maarif Nezareti'nden, Abdülgafur Rüşdi Efendi'nin Alanya Rüşdiye Mektebi'nde görevlendirilmesinin tasdik edilmesini istemiştir (BOA. MF. MKT. 435:6. L.3).

Muallim-i Evvel Abdülgafur Rüşdi Efendi, Alanya Rüşdiye Mektebi’nde görevlendirilmiş, ancak mektebin önceki muallim-i evveli Yahya Efendi görevinden ayrılmamıştı. Bu durum karşısında Yahya Efendi 17 Kasım 1898 tarihinde Maarif Nezareti'ne bir telgraf çekmiştir. Bu telgrafta, emeklilik talebinin henüz gerçekleşmediğini, buna rağmen Konya Vilayeti tarafindan Antalya Rüşdiye Mektebi Muallim-i Evveli Abdülgafur Rüşdi Efendi’nin, kendi yerine görevlendirildiğini ifade etmiştir. Ayrıca Yahya Efendi, Maarif Nezareti'nden, uzun yıllar maarife hizmet ettiğini ve çaresiz olduğunu belirterek, emekliliğin icrasına kadar istihdam edilmesi hususunda telgrafla emir verilmesini talep etmiştir (BOA. MF. MKT. 435: 6. L.4).

Konya Vilayeti'nin 31 Ekim 1898 tarihli telgrafi üzerine de, Mekâtib-i Rüşdiye İdaresi’nde evrak üzerinde bir tetkik yapılmıştı. Bunun neticesinde de Maarif Nezareti'nde, Alanya Rüşdiye Mektebi Muallim-i Evveli Yahya Efendi'nin emekliye ayrılma talebine veya diğer bir mahalle nakledilmesi hakkında bir müracaata rastlanmamıştı. Bunun yanında Maarif Nezareti'ne göre, emeklilik talebinde bulunan bir kimsenin, emekliliği gerçekleşmeden yerine bir başkasının tayin edilmesi de Tekaüd Nizamnamesi hükümlerine aykırıdı. Bu nedenle Maarif Nezareti tarafından Alanya Rüşdiye Mektebi Muallim-i Evveli Yahya Efendi'nin açık okullardan birine tayin edilmesi, yerine de Abdülgafur Rüşdi Efendi'nin nakledilmesinin uygun olacağına karar verilmiştir (21 Kasım 1898) (BOA. MF. MKT. 435: 6. L.5).

Daha sonra, Alanya Rüşdiye Mektebi Muallim-i Evveli Yahya Efendi'nin emekliliği hakkında, Konya Vilayeti'ne bir tebligat yapıldığını tespit eden

8 Bunun yanında Konya Vilayeti, aynı yazıda Antalya ve Alanya rüşdiye mektepleri muallim-i sanilerinin henüz asaletlerinin tasdik edilmediği ve bu nedenle de almış oldukları yarım maaşla geçinemediklerinden dolayı asaletlerinin tasdik edilmesini Maarif Nezareti'nden talep etmiştir. BOA. MF. MKT 435:6. Lef.2. 
Maarif Nezareti, Yahya Efendi'nin kaç kuruş maaşla ve hangi tarihten itibaren emekliye ayrıldığının bildirilmesini, Konya Vilayeti'nden talep etmiştir (22 Aralık 1898) (BOA. MF. MKT. 435:6. L.6).

$\mathrm{Bu}$ talep üzerine, Alanya Rüşdiye Mektebi Muallim-i Evveli Yahya Efendi'nin, mahallinden verilen bilgi neticesinde, 31 Ekim 1898 tarihinden itibaren aylık 293 kuruş maaşla emekliye ayrıldı ğı Konya Vilayeti tarafından, Maarif Nezareti'ne bildirilmiştir ( 25 Aralık 1898) (BOA. MF. MKT. 435:6. L.7).

Maarif Nezareti de, Yahya Efendi'nin emekliye ayrılması sebebi ile boş kalan Alanya Rüşdiye Mektebi Muallim-i Evvelliği’ne aylık 500 kuruş maaş ile Antalya Rüşdiye Mektebi Muallim-i Evveli Abdülgafur Rüşdi Efendi'yi tayin etmiş ve bu tayin işlemi Muhasebe tarafından kayda alınmıştır ( 7 Ocak 1899) (BOA. MF. MKT. 435:6. L.8).

\subsection{DERS KİTAPLARI}

Osmanlı Devleti'nde XIX. yüzyıldan itibaren açılmaya başlanan rüşdiye mekteplerinde eğitim gören talebelerin istifade etmesi için, Maarif Nezareti tarafından konunun uzmanı olan kişilere muhtelif ders kitabı ile risaleler hazırlatılmış ve bu eserler talepleri doğrultusunda mekteplere gönderilmiştir (Altıova 2010 : 244, Yıldız: 2013: 146). Rüşdiye mekteplerine gönderilen bu eserler, bedeli mukabilinde talebelere satılmış ve elde edilen para Maarif Nezaret'ine gönderilmiştir (BOA. MF. MKT. 4: 143, BOA. MF. MKT. 69: 43).

Alanya Rüşdiye Mektebi de, Maarif Nezareti'nden bazı kitap ve risaleler ile muhtelif haritalar talep etmiştir. Bu talep üzerine, Maarif Kitaphanesi'nde mevcut olan kitap, risale ve haritalar, fiyatları gösteren bir liste ile birlikte posta yoluyla Alanya Rüşdiye Mektebi'ne gönderilmiştir. Ayrıca Maarif Nezareti, bu konu hakkında, Konya Vilayeti’ne bilgi vermiştir (12 Eylül 1872) (BOA. MF. MKT. 4: 143. L.1).

Maarif Nezareti tarafindan Alanya Rüşdiye Mektebi talebelerine satılmak için gönderilen kitap ve risaleler arasında, Binâ, Dürr-i Yektâ, Nasihat-ül Hükemâ, Talîm-i Farîsî, Tarih-i Osmanî, Emsile, Maksûd, Avâmil, Risâle-i Selâse, Gülistân ve Coğrafya Risâlesi gibi eserler bulunmaktadır (BOA. MF. MKT.4: 143 L.2).

Maarif Nezareti tarafindan Alanya Rüşdiye Mektebi gibi, Antalya Rüşdiye Mektebi talebeleri için de, ihtiyaç olan kitap ve risaleler bu mektebe gönderilmiştir. Bir müddet sonra Antalya ve Alanya Rüşdiye mekteplerine gönderilmiş olan kitap ve risalelerin talebelere satılması sonunda 696 kuruş 30 para 
elde edilmiştir. Bu miktarın 243 kuruş 30 parası satılan eserlerin anaparası ve 453 kuruş da satılan eserlerden elde edilen kard1. 696 kuruş 30 para, altıllık olarak, adı geçen nezarete gönderilmek üzere geçici olarak vezneye teslim edilmiştir. Bu konu hakkında Antalya Mutasarrıflığ tarafindan 19 Ağustos 1881 tarihinde Maarif Nezareti'ne bilgi verilmiştir. Ancak bu para hakkında Antalya Mutasarrıflı̆ı, Konya Vilayeti'ne usulüne uygun olarak bilgi vermemiş, ayrıca müfredat pusulası düzenlememişti. Bu nedenle Maarif Nezareti tarafından 13 Eylül 1881 tarihinde, Antalya Mutasarrıflğı'nın yazısı iade edilerek, eksik evrakların tamamlanması konusunda gerekli işlemin yapılması Konya Vilayeti'nden istenmiştir (BOA. MF. MKT. 69: 43).

\subsection{TEFTIŞ̧ VE SORUŞTURMALAR}

XIX. yüzyılın son yıllarında Alanya'nın maarif teşkilatı ve burada bulunan mektepler yetkili kişiler tarafından teftiş edilmiştir. Bunun yanında Alanya'daki mekteplerde görev yapan muallimler de çeşitli nedenlerden dolayı soruşturma geçirmişlerdir. Mesela; Konya ve Ankara vilayetlerine mensup maliye müfettişleri tarafından, Alanya'daki maarif teşkilatında bir teftiş yapılmış ve bunun neticesinde de 28 Mart 1885 tarihinde teftiş layihası hazırlanmıştır. Bu layihada, ilk önce Alanya'da bir rüşdiye mektebi ve bir kaç tane de sıbyân mektebi bulunduğu, kazada maarif komisyonunun teşkil edilmemiş olduğu ve aşarın 4/1'nün 7/1'i olan maarif hissesinin hepsinin, Antalya Mutasarrıflı̆ğ'na gönderildiği gibi hususlar tespit edilmiştir. Daha sonra da Alanyada maarif teşkilatı hakkında soruşturma gerektirecek, bir halin bulunmadığ1 sonucuna varılmıştır (BOA. MF. MKT. 87: 90. L.1).

Alanya'da yapılan bu teftiş sonucu hakkında Divan-1 Muhasebat Başkanlığı tarafindan 21 Mayıs 1885 tarihinde Meclis-i Maarif'e bir tezkere gönderilmiştir. Bu tezkere, Meclis-i Maarif'te görüşülerek, diğer kazalarda olduğu gibi Alanya'da da bir maarif komisyonunun teşkil edilmesi ${ }^{10}$ ve maarifin terakki etmesi hususunda gayret edilmesi için Alanya Kaymakamlığı'na gerekli uyarının yapılması konusunda Konya Vilayeti'ne bir yazı gönderilmesine karar verilmiştir (BOA. MF. MKT. 87: 90. L.2). Meclis-i Maarif'in bu talebi, Maarif Nezareti tarafından 29 Ağustos 1885 tarihinde Konya Vilayeti'ne

9 Altılık; İkinci Mahmud devrinde ve 1833 ve 1839 senelerinde basılan bir sikkenin adıdır. Beşlikten daha az mağşuş olan bu paranın kıymeti 240 para yahut 6 kuruştu. M. Zeki Pakalın, Tarih Deyimleri ve Terimleri Sözlü̈̆ü, Milli Ĕ̈itim Basımevi İstanbul 1971, L/53

10 Bu teftişten bir müddet sonra Alanya'da Maarif Komisyonu'nun teşkil edildiği bilinmektedir. 1887 yılında Alanya Maarif Komisyonunun Reisi; Hüseyin Hüsnü Efendi, Azaları; Mehmet Ali Efendi, Hüseyin Efendi ve Ahmet Efendidir. Bu konuda bakınız; Konya Vilayeti Salnamesi, Konya 1305, s.187. 
bildirilmiş ve bu konuda gerekli işlemin yapılması istenmiştir (BOA. MF. MKT. 87: 90. L.3).

Bunun yanında Alanya Rüşdiye Mektebi muallimleri de bazı zamanlarda soruşturmaya konu olmuşlardır. Mesela; Maarif Nezareti Mekâtib-i Rüşdiye Dairesi'ne, Alanya Rüşdiye Mektebi Muallim-i Evveli Halil Efendi’nin görevinde tembellik gösterdiğine dair bir ihbar yapılmıştır. Bunun üzerine adı geçen dairece 4 Haziran 1907 tarihinde, bu konuda Konya Vilayeti Maarif Müdürlüğü'ne gerekli tahkikatın yapılması konusunda emir verilmesi Maarif Nezareti'nden talep edilmiştir (BOA. MF. MKT. 1006: 68. L.1). Maarif Nezareti de 13 Temmuz 1907 tarihinde Halil Efendi hakkında gerekli soruşturmanın yapılmasını Konya Vilayeti Maarif Müdürlüğ̈̈’nden istemiştir (BOA. MF. MKT. 1006: 68. L.2).

\section{Sonuç}

Osmanlı Devleti'nin klasik döneminde bütün ülkede olduğu gibi, Alanyada da geleneksel örgün eğitim kurumlarından olan medreseler ve sıbyân mektepleri faaliyet gösteriyordu. Ancak ülkede XIX. yüzyıldan itibaren modernleşme çalışmalarının başlaması, eğitim hayatında da kendini göstermiş ve buna bağlı olarak modern mektepler açılmaya başlanmıştır. Bu mekteplerden birisi de mahalli hayırsever kişiler tarafından 1861 yılında inşa edilerek, hizmete giren Alanya Rüşdiye Mektebi'dir.

$\mathrm{Bu}$ mektepte yıllar içinde çeşitli muallimler görev yapmıştır. Bunlar arasında Yahya Efendi, Abdülgafur Rüşdi Efendi, Halil Efendi, Mehmet Rahmi Efendi, Sadullah Efendi, Mehmet Efendi, Ahmet Efendi, Abdurrahman Efendi gibi muallimler ile Ali Efendi, Arif Efendi, Fehmi Efendi gibi rıka (hüsn-i hatt) hocaları bulunmaktadır. Ayrıca Süleyman Ağa, Hasan Ağa ve Mustafa Ağa gibi bevvâplar bu mektepte görev yapmışlardır.

Alanya Rüşdiye Mektebi'ne yıllara göre devam eden talebe sayısı ile ilgili sağlıklı bir bilgi bulunmamaktadır. Ancak elde bulunan verilere göre, bu mektebin yıllık talebe sayısının ortalama 59 olduğu söylenebilir.

Alanya Rüşdiye Mektebi’nde talebelerin okuduğu ders kitapları ve risâleler, onlara bedeli mukabilinde satılmış ve elde edilen para Maarif Nezareti'ne gönderilmiştir. Bu mektepte talebelere satılan kitap ve risâleler arasında Binâ, Talîm-i Farîsî, Tarih-i Osmani, Dürr-i Yektâ, Emsile, Nasîhat-ül Hükemâ, Maksûd, Avamil, Risâle-i Selâse, Gülistân ve Coğrafya Risâlesi gibi eserler bulunmaktadir.

Alanya Rüşdiye Mektebi'nde görev yapan muallimler aylık olarak muhtelif miktarlarda maaş almışlardır. Mesela; 1896 yılında Rıka (Hüsn-i Hatt) Mu- 
allimi Fehmi Efendi aylık 80 kuruş, 1899 yılında Muallim-i Evvel Abdülgafur Rüşdi Efendi aylık 500 kuruş maaş alıyordu. Emekli olan rüşdiye mektebi muallimlerine de devlet tarafından emekli aylığı bağlanıyordu. Bunlar arasında 37 y1 hizmet yaptıktan sonra emekliye ayrılan ve 293 kuruş emekli aylığ1 bağlanan Muallim-i Evvel Yahya Efendi de bulunmaktadır.

Bunun yanında Alanya Maarif Sistemi, maliye müfettişleri tarafindan teftiş edilmiş, ayrıca rüşdiye mektebinde görevli bir muallim de, hakkında ileri sürülen bazı iddialardan dolayı soruşturma geçirmiştir.

Yarım asırdan fazla bir zaman Türk eğitim hayatına hizmet veren Alanya Rüşdiye Mektebi; 6 Ekim 1913 tarihli Tedrisat-1 İbtidaiye Kanun-u Muvakkati'nin yürürlüğe girmesi üzerine, ülkedeki diğer rüşdiye mektepleri gibi, öğretim süresi altı yıla çıkarılan ibtidai mekteplerin çatısı altına alınarak, bağımsız mektep olarak faaliyet yapmasına son verilmiştir.

Sonuç olarak denilebilir ki; Osmanlı ülkesinde açılan rüşdiye mektepleri, Osmanlı modernleşmesinin eğitim alanındaki eserlerinden birisidir. Alanya Rüşdiye Mektebi'ni de bu kapsamda değerlendirmek gereklidir. Bu mekteplerin işleyişi, 1869 tarihli Maarif-i Umumiye Nizamnamesi’ne, iç talimatlara ve çeşitli tarihlerde ç1karılan programlara göre yürütülmüş̧ür. Bu yönleri ile de Cumhuriyet dönemi eğitim sistemini etkilemiştir.

\section{Kaynaklar}

\section{ARŞIV BELGELERİ}

\subsection{Osmanlı Arşivi Belgeleri}

\subsubsection{Bab-I Ali Belgeleri}

Sadaret Mektûbi Kalemi Meclis-i Vâlâ Yazı̧̧malarına Ait Belgeler (BOA. A. MKT. MVL). Meclis-i Vâlâ Riyâseti Belgeleri (BOA. MVL).

\subsubsection{Nezaretler}

\subsubsection{Dâhiliye Nezareti}

Umûr-1 Mahalliye-i Vilâyât Müdüriyeti Belgeleri (BOA. DH. UMVM).

\subsubsection{Maarif Nezareti}

Mektûbi Kalemi Belgeleri (BOA.MF. MKT). 


\section{KITTAPLAR VE MAKALELER}

Altınova, Ayşegül (2010). "Osmanlı Modernleşmesinde Rüşdiye Mektepleri”, yayımlanmamış doktora tezi, Ankara: Gazi Üniversitesi.

Aydın, Mithat (2011), "Denizli'de Rüşdiyelerin Kuruluşu ve Gelişimi”, Belleten LXXV/274, Ankara: Türk Tarih Kurumu Yayınları, s. 815-843.

Baltacı, Cahit (1976). XV-XVI Asırlarda Osmanlı Medreseleri Teşkilat-Tarih, İstanbul: İrfan Matbaası.

Bozkurt, İbrahim (2008). "Tanzimat'tan Cumhuriyet'e Modernleşme Sürecinde Mersinde Eğitim”, Mersin Üniversitesi Eğitim Fakültesi Dergisi 2, s.197-213.

Devellioğlu, Ferit (1998). Osmanlıca Türkçe Ansiklopedik Lûgat, Ankara: Aydın Kitabevi.

Ergün, Mustafa (1996). İkinci Meşrutiyet Döneminde Ĕgitim Hareketleri, Ankara: Ocak Yayınları.

Evliya Çelebi Seyahatnamesi (1996). Haz. Mümin Çevik, C.9, İstanbul: Üçdal Neşriyat.

Gönüllü, Ali Rıza (2008). Meşrutiyet'ten Cumburiyet'e Alanya (1908-1938), Ankara: Atatürk Araştırma Merkezi Yayınları.

Gönüllü, Ali Rıza (2010). Cumburiyet Döneminde Antalya (1923-1960), İstanbul: Tarihçi Kitapevi.

Görür, Emel Demir (2015). “İnas Rüşdiye Mektepleri: Yanya Hamidiye İnas Rüşdiye Mektebi Örneği”, Uluslararası Sosyal Araştırmalar Dergisi 36, s.311-322.

İpşirli, Mehmet (2003). "Medresetü'1-Kudât Maddesi”, Türkiye Diyanet Vakfi İslam Ansiklopedisi, C.28, İstanbul: Türkiye Diyanet Vakfi Yayınları, s.343-344.

Kaya, Fatma, (2007). “Kala-i Sultaniye (Çanakkale) Sancağı'nda Eğitim Kurumları”, Atatürk Üniversitesi Sosyal Bilimler Enstitüsü Dergisi 9/1, s.237-251.

Kılıç, Fahri-Tarhan, Murat (2014). “Tanzimat'tan Cumhuriyet'e Bolu'da Eğitim Uygulamaları”, Abant İzzet Baysal Üniversitesi Sosyal Bilimler Enstitüsü Dergisi 3, s.152-190.

Kodaman, Bayram (1980). Abdülhamid Devri Ë̆itim Sistemi, İstanbul: Ötüken Yayınları. Kuran, Abdullah (1969). "Karamanlı Medreseleri”, Vakiflar Dergisi 8, s.209-224. 
Maarif-i Umumiye Nezareti (1329). Tedrisat-ı İbtidaiye Kanun-u Muvakkati, İstanbul: Matbaa-i Amire.

Maarif-i Umumiye Nizamnamesi (1286). Istanbul: Matbaa-i Amire.

Öztürk, Cemil (2008), “Rüşdiye Maddesi”, Türkiye Diyanet Vakfi İslam Ansiklopedisi, C.35, İstanbul: Türkiye Diyanet Vakfı Yayınları, s.300-303.

Şemseddin Sami (1989). Kâmûs-ı Türkî, İstanbul.

Sönmez, Veysel (1989). “Türkiye’de Öğretmenin Ekonomik Durumu”, $\mathrm{Ha}^{-}$ cettepe Üniversitesi Eğitim Fakültesi Dergisi 4, s.77-84.

Türkol, Kamuran (2007). Eyüp Askeri Rüssdiyesinin (1910-1916) Giden Evrak Defteri ve Değerlendirilmesi, yayımlanmamış doktora tezi, Kırıkkale: Kırıkkale Üniversitesi.

Pakalın, M. Zeki (1971). Tarih Deyimleri ve Terimleri Sözlüğü, C.1, İstanbul: Milli Eğitim Bakanlığ̣ Yayınları.

Umûm Mekâtib-i Rüşdiyeye Mahsûs Olarak Bu Kere Tâdilen Tertip Edilen Ders Programıdir (1315). İstanbul: Matbaa-i Amire.

Uzunçarş11, İsmail Hakkı (1984). Osmanlı Devletinnin İlmiye Teşkilatı, Ankara: Türk Tarih Kurumu Yayınları.

Ünal, Uğur (2015). II. Meşrutiyet Öncesi Osmanlı Rüşdiyeleri (1897-1907), Ankara: Türk Tarib Kurumu Yayınları.

Yıldız, Hatip (2013). "Eğil Rüşdiye Mektebinin Tarihçesi ve Eğitim Kadrosu”, Dicle Üniversitesi Sosyal Bilimler Enstitüsü Dergisi, s.142-161.

166 Numaralı Muhâsebe-i Vilâyet-i Anadolu Defteri (937/1530) Hudâvendigâr, Biga, Karesi, Saruhân, Aydın, Menteşe, Teke ve Alâiye Livalar "Dizin ve Tıpkı Basım" (1995). Ankara: Devlet Arşivleri Genel Müdürlüğ̈̈ Yayınlart.

\section{SÜRELI YAYINLAR}

Hürriyet Gazetesi.

İlmiye Salnamesi (1334), Matbaa-i Amire Dârüll Hilâfeti'l Âliye.

Konya Vilayeti Salnamesi (1285), Konya.

Konya Vilayeti Salnamesi (1286), Konya.

Konya Vilayeti Salnamesi (1287), Konya.

Konya Vilayeti Salnamesi (1288), Konya. 
Konya Vilayeti Salnamesi (1289), Konya. Konya Vilayeti Salnamesi (1290), Konya. Konya Vilayeti Salnamesi (1291), Konya. Konya Vilayeti Salnamesi (1292), Konya. Konya Vilayeti Salnamesi, (1293) Konya. Konya Vilayeti Salnamesi, (1294) Konya. Konya Vilayeti Salnamesi (1295), Konya. Konya Vilayeti Salnamesi (1296), Konya. Konya Vilayeti Salnamesi (1298), Konya. Konya Vilayeti Salnamesi (1299), Konya. Konya Vilayeti Salnamesi (1300), Konya. Konya Vilayeti Salnamesi (1301), Konya. Konya Vilayeti Salnamesi (1303), Konya. Konya Vilayeti Salnamesi (1305), Konya. Konya Vilayeti Salnamesi (1306), Konya. Konya Vilayeti Salnamesi (1307), Konya. Konya Vilayeti Salnamesi (1309) Konya. Konya Vilayeti Salnamesi (1312), Konya. Konya Vilayeti Salnamesi (1314), Konya. Konya Vilayeti Salnamesi (1317), Konya. Konya Vilayeti Salnamesi (1322), Konya.

Resmi Gazete.

Salname-i Nezareti Maarif-i Umumiye (1316), Matbaa-i Amire İstanbul.

Salname-i Nezareti Maarif-i Umumiye (1317), Matbaa-i Amire Dârül Hilâfeti'l Âliye.

Salname-i Nezareti Maarif-i Umumiye (1318), Matbaa-i Amire Dârül Hilâfeti'l Âliye.

Salname-i Nezareti Maarif-i Umumiye (1319), Matbaa-i Amire Dârül Hilâfeti'l Âliye.

Salname-i Nezareti Maarif-i Umumiye (1321), Asr Matbaası İstanbul. 


\begin{abstract}
Alanya Rushdie School (1861-1913)

Rushdies were one of the educational institutions established during renovation period. Students that graduated from primary schools are accepted to there schools. Rushdie schools had variations like; male, female or military. In Alanya, addition to traditional educational institutions such as madrasas and primary school, modern educational institutions began to open from Tanzimat period. The first of these was Rushdie built by charitable people and opened in Alanya in 1861. After opening of Rushdie School, teacher assignment is made by the government. Students textbooks studying in this school, sent by the Ministry of Education and are given to the students with price. The teachers who served in Alanya Rushdie schools have received salaries and allowances and ones who completed sufficient service time are retired. Alanya Ministry of Education has been inspected administratively and financially. Also Alanya Rushdie School teachers have been investigated when a complaint occured. After October 6, 1913 dated law of Temporary Primary Law, Alanya Rushdie School is also closed as other schools in the country.
\end{abstract}

Keywords: Education, madrasas, Rushdie school, teacher, salary, retired. 